\begin{tabular}{|c|c|c|}
\hline$r$ & Our Nature & $\begin{array}{l}\text { ISSN: 1991-2951 (Print) } \\
\text { ISSN: 2091-2781 (Online) }\end{array}$ \\
\hline $\begin{array}{l}\text { lature Consenvalion \& } \\
\text { Heallh Care Councill } \\
\text { Brothoga Nobodi }\end{array}$ & Journal homepage: http://nepjol.info/index.php/ON & (c) (1) (): \\
\hline
\end{tabular}

\title{
Population status and breeding ecology of Black Kite Milvus migrans (Boddaert, 1783) in Pokhara Valley, Nepal
}

\author{
Namuna Khand $^{1}$, Shaligram Adhikaree ${ }^{1}$, Milan Khare ${ }^{1 *}$ and Ramji Gautam² \\ ${ }^{1}$ Department of Zoology, Post Graduate Campus, Tribhuvan University, Biratnagar, Nepal \\ ${ }^{2}$ Department of Zoology, Prithvi Narayan Campus, Tribhuvan University, Pokhara, Nepal \\ *E-mail: milan.kharel@pgc.tu.edu.np
}

\begin{abstract}
The present study attempted to provide basic knowledge on population status, breeding success and general behaviours of Black kites in the Pokhara Valley of Nepal. Nesting and roosting sites were directly observed to count the bird in the fields during the study period from December 2019 to May 2020. A total of 308 individuals of Black kites were recorded. The highest and least number was recorded in February $(n=67)$ and May $(n=31)$ respectively. The breeding success was found to be $47.22 \%$. The average height, girth and canopy cover of the nesting tree were found at $16.59 \mathrm{~m}, 2.23 \mathrm{~m}$ and $63.30 \%$ respectively. About $67 \%$ of nests observed were found active during the breeding season. The Spearman rank correlation coefficient showed a perfect positive relationship between the number of chicks and the number of the nest $(\mathrm{r}=1)$. Bombax ceiba and Dalbergia sissoo were the trees on which the maximum number of nests were observed.
\end{abstract}

Key words: Raptor census, hatching success, nesting behaviour, threats assessment

DOI: https://doi.org/10.3126/on.v19.i1.41245
Manuscript details: Received: 19.07.2021 / Accepted: 03.11.2021
Citation: Khand, N., S. Adhikari, M. Kharel and R. Gautam 2021. Population status and breeding ecology of Black Kite Milvus migrans
(Boddaert, 1783) in Pokhara Valley, Nepal. Our Nature 19(1): 46-53. DOI: https://doi.org/10.3126/on.v19.i1.41245
Copyright: (C) Khand et al., 2021. Creative Commons Attribution - Non Commercial 4.0 International License.

\section{Introduction}

The black kite Milvus migrans (Boddaert, 1783) is a bird of prey (Family: Accipitridae), locally known as 'Kalo cheel' (Inskipp et al., 2016). This gregarious and scavenger bird attains the length of $55-60 \mathrm{~cm}$ which can be easily identified with its highly streaked dark brown covert, angled wing and forked tail (Arlott, 2015). Black kite is a summer resident in Asia and Europe that winters mostly in western Africa (Panuccio et al., 2014). It has been recorded in almost all protected areas of Nepal ranging between 75 to $4000 \mathrm{~m}$ altitudes (Inskipp et al., 2016). It is a common resident and passage migrant (Grimmett et al., 2014). In winter, they form large communal roosts and their flocks may fly about sitting at the roost (Ali and Ripley, 1995).
Black kites breed in more tropical regions and often remain in the same area year-round if resources remain abundant (Vinuela and Sunyer, 1992; Fergunson-Lees and Christie, 2001). They have a ritualized aerial courtship, which consists of extremely loud calls to one another and grappling. Ritual courtship behaviour typically begins in March (Ferguson-Lees and Christie, 2001). Black kites play an essential role as efficient scavengers within their ecosystems. They scavenged road kills which may help to reduce the spread of disease (Richrds, 1998). They prayed upon many crop-destroying pests. Due to ingestion of rodenticide, illegal poisoning and changes in agricultural practices, Black kites were in decline (Heneberg et al., 2016). 


\section{Khand, Adhikaree, Kharel and Gautam / Our Nature | December 2021 | 19 (1): 46-53}

Kumar et al. (2014) recorded the world's highest population density of Black kites in Delhi (India) which has declined since 1960. Sharma and Soni (2018) reported that the winter season adversely affects the population of Black kites in the study area because of the non-availability of preferential food in Rajasthan, India. BCN (2016) performed an urban bird survey using the line transect method found 89 kites in winter whereas 79 in the summer season.

Altitudinal migration of raptors consists of relatively short distance seasonal movements between high altitude breeding sites and lower altitude overwintering areas (Juhant and Bildstein, 2017). Literák et al. (2017) found that M. migrans breed in the western Palearctic and Central Asia. Sharma and Soni (2017) studied the feeding behaviour of Black kites in different microhabitats and recorded the seven variables viz. standing on the ground, snatching, hovering, perch hunting, gliding and hovering, intraspecific and interspecific cleptoparasitism. Mazumdar et al. (2017a) found Black kites showing preroosting displays as response variables highest in summer (during the monsoon) and lowest in

\section{Materials and methods}

\section{Study area}

The present study was carried out in Pokhara valley $\left(28^{\circ} 12^{\prime} 30^{\prime \prime} \mathrm{N}, 83^{\circ} 59^{\prime} 20^{\prime \prime} \mathrm{E}\right)$, Kaski district of Nepal. Forests cover about $44.6 \%$ of the total area of the district. Pokhara is one of the metropolitan cities in Nepal, which serves as the

\section{Climate}

The Pokhara valley has a warm and temperate climate with an average annual temperature of $18.3{ }^{\circ} \mathrm{C}$. The highest and lowest average of $23.1^{\circ} \mathrm{C}$ in June and $11.0^{\circ} \mathrm{C}$ in January respectively. The rainfall here is around $4851 \mathrm{~mm}$ per year (Climate Data, 2021).

\section{Flora and fauna}

The dominant trees are Cotton tree (Bombax ceiba), Cutch (Acacia catechu), Indian rosewood (Dalbergia sissoo), Needlewood (Schima wallichii), Indian chestnut (Castanopsis indica), Mango (Mangifera indica), Burflower-tree (Neolamarckia cadmba), Banyan (Ficus benghalensis), Sacred fig (Ficus religiosa) and Sal (Shorea robusta) which provide roosting and winter. Mazumdar et al. (2017b) studied nests of Black kites $(n=3)$ in Kolkata, to get quantitative data on the nest-building materials used by the Black kites. Kharel (2018) reported six species of birds to belong to the family Accipitridae including Black kite from Betana wetland, Morang, east Nepal. Llorente-Llurba (2019) showed a positive relationship between the rodent's percentage in the diet and breeding success. Black kites tend to re-use old nests where possible; likewise, Asian Woolly-necked storks normally re-use nests in successive breeding years, which limits the opportunities for Black kites to take over their nests (Ghimire et al., 2020).

Since the data on population status and hatching success of Black kite in Pokhara valley is lacking, the present study aimed to estimate population, know the breeding success, identify the nesting trees, access the major threats to Black kites which might be helpful to protect the habitat of the species and assist in their conservation.

capital of Gandaki province. It lies at an average elevation of $822 \mathrm{~m}$, covering an area of 464.24 $\mathrm{km}^{2}$ (Metropolitan, 2021). The study area was divided randomly into nine blocks, viz., Industrial area (Audhyogik Chhetra), Bhadrakali, Gumba, Bagar, Batulechaur, Lamachaur, Parsyang, Airport and Birauta (Fig. 1).
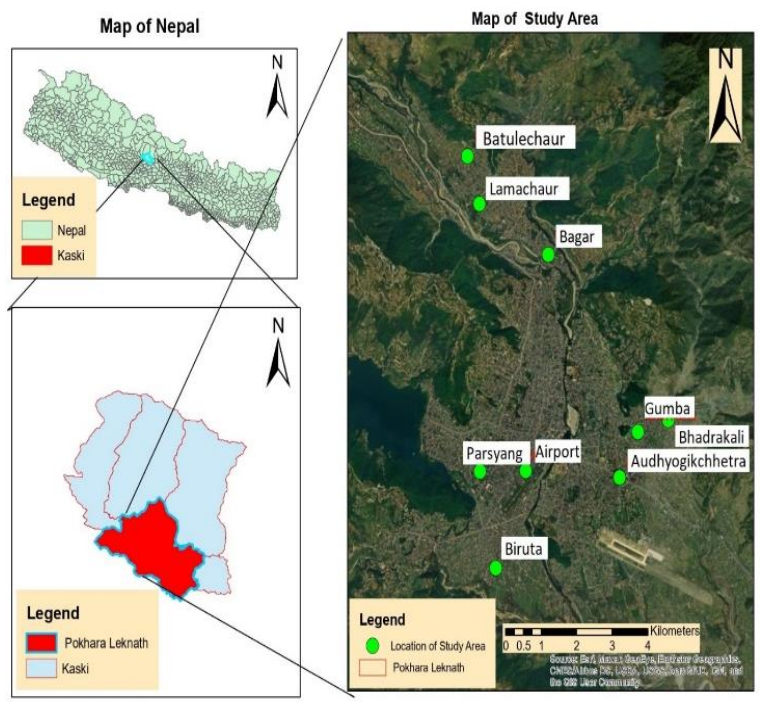

Figure 1. Map of study area showing sampling blocks. 


\section{Khand, Adhikaree, Kharel and Gautam / Our Nature | December 2021 | 19 (1): 46-53}

nesting habitat for Black kite. The Pokhara valley is rich in avifauna like Asian koel (Eudynamys scolopaceus), Kalij pheasant (Lophura leucomelanos), Spangled drongo

(Dicrurus hottentottus), Spotted owlet (Athene brama), Brown fish owl (Ketupa zeylonensis), etc. along with mammalian fauna such as Jungle cat (Felis chaus), Leopard (Panthera pardus), Rhesus macaque (Macaca mulatta), etc.

\section{Population count}

Black kites roosting in the trees were directly observed within $50 \mathrm{~m}$ on both sides of the road following the line transect method early in the morning (6:00 to $10: 00 \mathrm{am})$ and evening (4:00 to 6:30 pm) in each visit from the Industrial area (Audhyogik Chhetra) and ended at Birauta. The population were counted in different situations roosting count, soaring count and nesting count. The species was identified following the field guide books (Inskipp and Inskipp, 1985; Ali et al., 1995; Grewal et al., 2002; Grimmett et al., 2014; Arlott, 2015).

\section{Nest count}

Black kite generally breeds from March to May/June. Breeding activities start from preparing nest and egg-laying (March), the incubation period (April), and the nesting period (March/June). The nest count and data on nesting trees were collected from December 2019 to May 2020. The occupied nests were identified and their geographical coordinates recorded with a Garmin eTrex 10 handheld GPS navigator. The DBH (Diameter at Breast Height) was measured with the help of measuring tape at $1.5 \mathrm{~m}$ above ground of each nesting tree. Canopy cover (\%) of nesting trees were measured with the help of a Spherical crown densiometer covering four cardinal directions of the nesting trees i.e., east, west, north and south. The measurements were then averaged and expressed as per cent canopy cover. The height of the trees (m) was measured using Abney's level.

\section{Threats assessment}

Threats on Black kites were identified through rapid assessment and questionnaire.

\section{Data analysis}

The data collected were analyzed using Microsoft Excel 10 and R Software (2019). The important data were presented in graphical forms (curves and bar diagrams) to depict population ecology.

\section{Results}

\section{Population status}

A total of 308 individuals of Black kites were observed between December 2019 to May 2020 in nine sampling blocks of Pokhara valley with an average population of 52 . The confidence limit of the population was found 39 to 65 . The average monthly population recorded was 57,64 , 67, 57, 32 and 31 in December, January, February, March, April and May respectively. The highest and least population recorded was 67 in February and 31 in May respectively (Fig. 2).

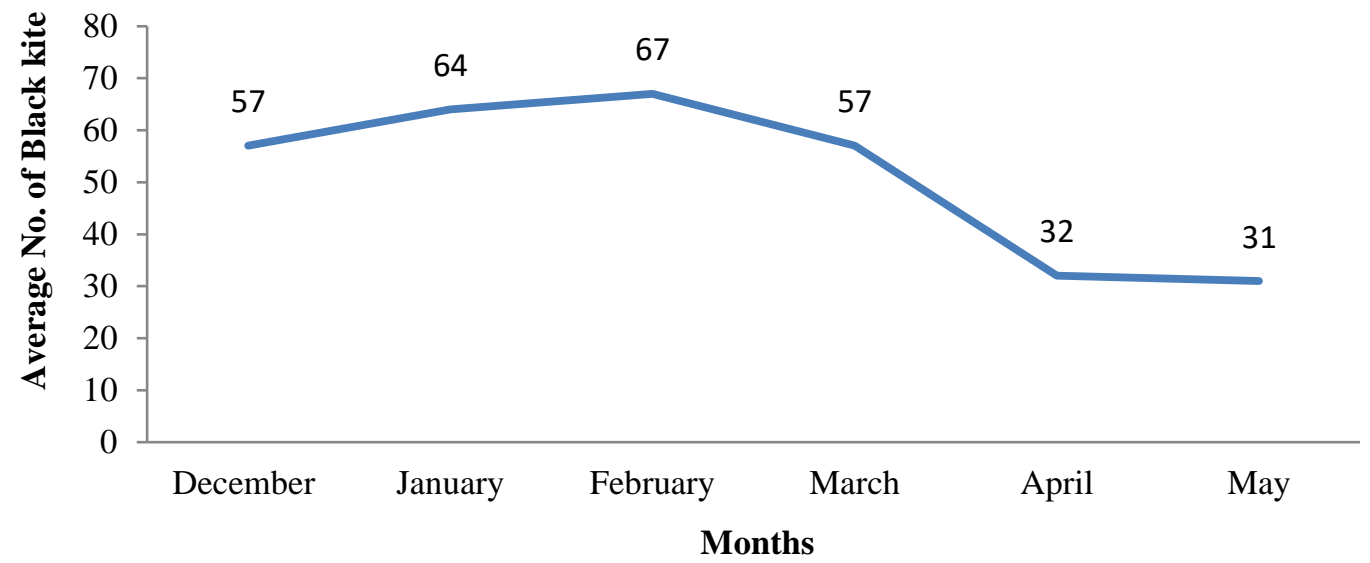

Figure 2. Monthly average population of Black kites. 


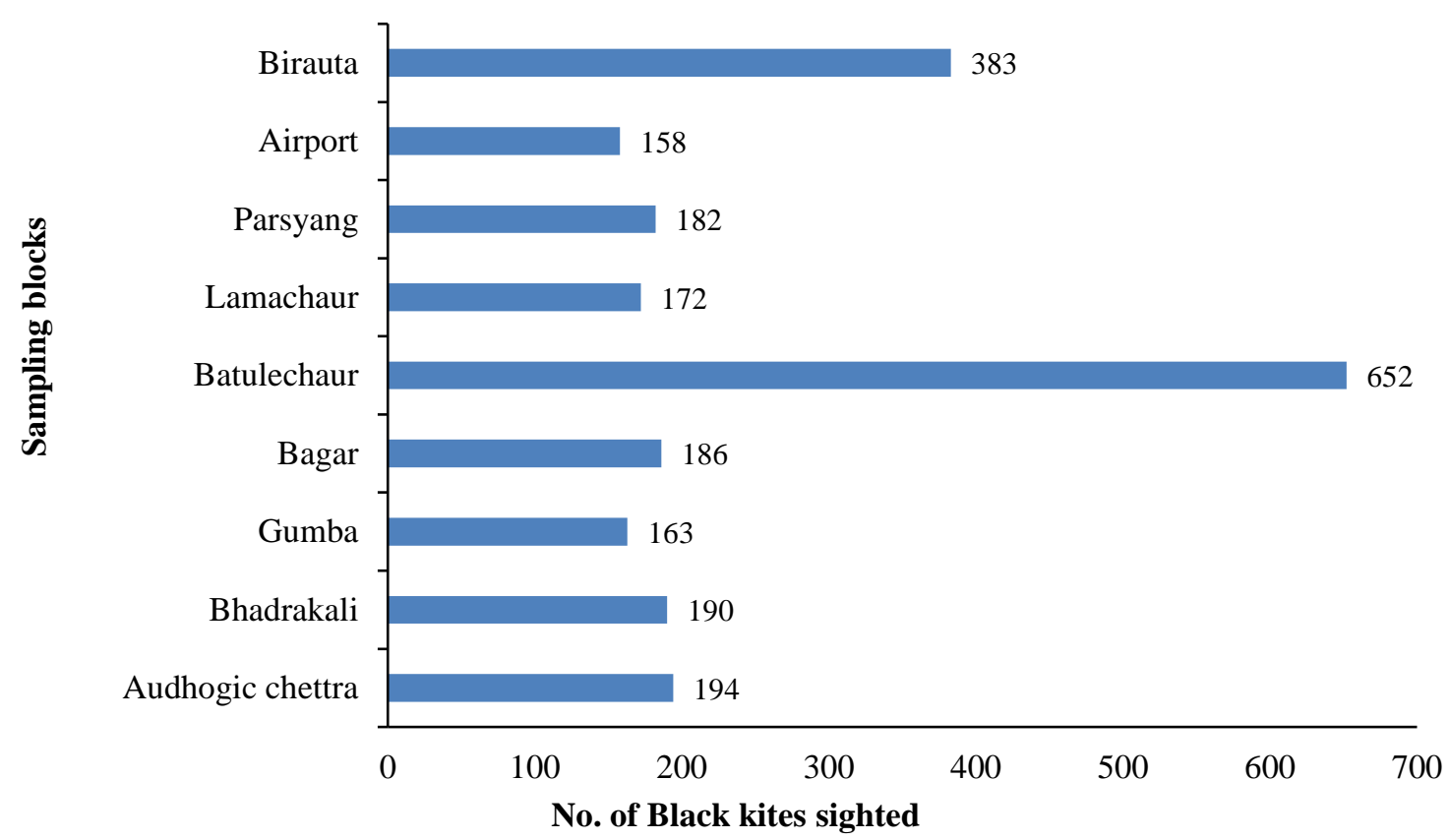

Figure 3. Block-wise sightings of Black kites in Pokhara valley.

The maximum and minimum individuals of most of the individuals of Black kites were Black kites were recorded in Batulechaur and recorded in February and the least number was Pokhara airport respectively (Fig. 3). Similarly, recorded in May (Fig. 4).

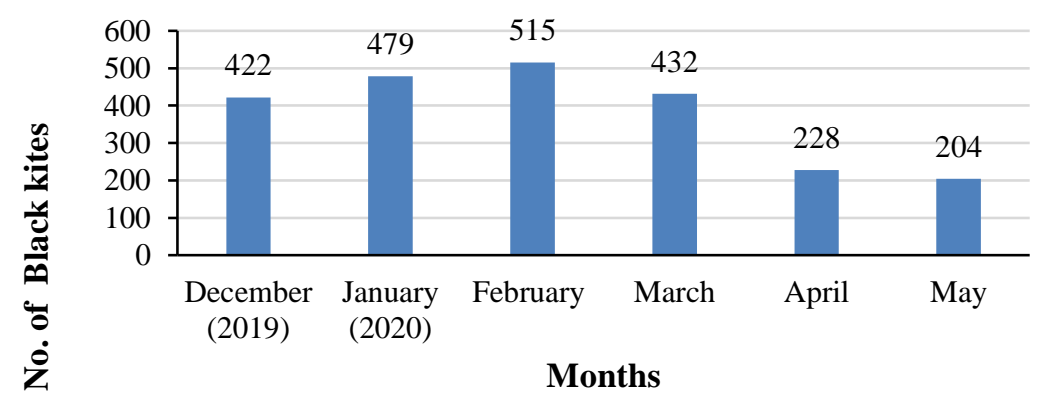

Figure 4. Month-wise total sightings of black kites in Pokhara valley.

\section{Morning activity}

Black kites flew early at 6:00 am in search of food often near the pig farm where they can easily get food and water. Some individuals were found roosting on branches of trees, others were soaring and chasing crows for food in the fields.

\section{Noon activity}

They roost in a branch of Bombax ceiba from around 12:00 to $1: 00 \mathrm{pm}$. After $2 \mathrm{hr}$ of roosting, they started soaring again.

\section{Evening activity}

Feeding activities were increased at about late afternoon. After $4 \mathrm{pm}$, birds walked slowly (bipedal) in the paddy field in search of prey. They flew at about 6:30 pm for roosting at night. 


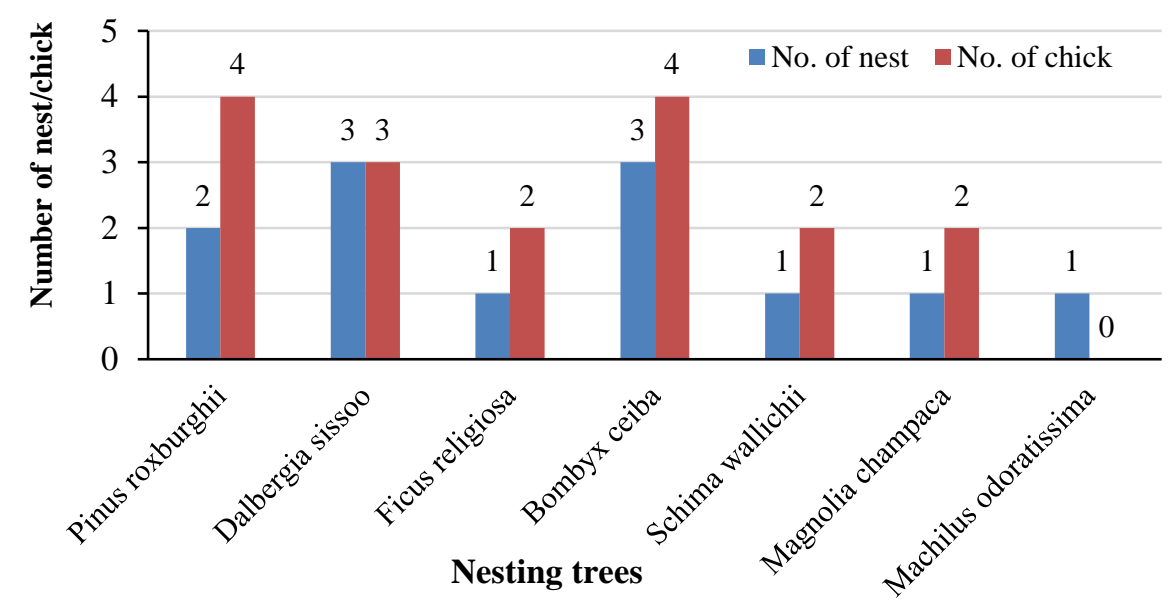

Figure 5. Number of chicks in the nesting trees.

\section{Nesting}

A total of 12 nests were observed during the breeding season 2019/2020 (Table 1). Regular nest maintenance by the bird was observed as growing chicks need more space. Black kites were observed making a single nest in a single tree and preferred to reuse the same old nest which was bigger and made on the tall Bombax ceiba. The highest number of nests was found in Dalbergia sissoo and Bombax ceiba. The highest, lowest and average nest height of Black kite was found $24.20 \mathrm{~m}, 10.00 \mathrm{~m} 16.59 \mathrm{~m}$ from the ground respectively with an average canopy of $63.30 \%$. The average girth of nesting trees was found to be $2.23 \mathrm{~m}$. The nests were made in the eight species of trees (Fig. 5). The Spearman rank correlation coefficient showed that there was a perfect positive relationship in-between the number of chicks and the number of nests $(r=1)$. The breeding success of Black kite was found $47.22 \%$ in the Pokhara valley. The breeding failure was caused by the felling of the nesting trees, shortage of food, competition with other bird species often with Large-billed crows (Corvus macrorhynchos). Pinus (Pinus roxburghii) Sissoo (Dalbergia sissoo), Peepal (Ficus relgiosa), Cotton tree (Bombyx ceiba), Needle woo (Schima wallichii), Michelia (Magnolia champaca), Fragrant Bay tree (Machilus odoratissima). There was no significant relationship between the number of nests with DBH, canopy cover and height of the tree (Table 2).

Table 1. Nesting trees, occupied nests and number of chicks of Black kite.

\begin{tabular}{|c|c|c|c|c|c|c|c|c|c|c|c|}
\hline \multirow{2}{*}{$\begin{array}{l}\text { Sampling } \\
\text { blocks }\end{array}$} & \multirow[b]{2}{*}{ Lat. (N) } & \multirow[b]{2}{*}{ Lon. (E) } & \multirow{2}{*}{$\begin{array}{l}\text { Alt. } \\
(\mathrm{m})\end{array}$} & \multicolumn{7}{|c|}{ Nesting tree species } & \multirow[b]{2}{*}{$\begin{array}{l}\text { - Total } \\
\text { chicks }\end{array}$} \\
\hline & & & & Pinus & Sissoo & Peepal & $\begin{array}{c}\text { Cotton } \\
\text { tree }\end{array}$ & $\begin{array}{c}\text { Needle } \\
\text { wood }\end{array}$ & Michelia & $\begin{array}{l}\text { Fragrant } \\
\text { Bay tree }\end{array}$ & \\
\hline$\overline{\text { Audhyogik }}$ & $28^{\circ} 12^{\prime} 10.4^{\prime \prime}$ & $84^{\circ} 00^{\prime} 20^{\prime \prime}$ & 825 & + & + & $1(2)$ & + & + & + & + & $1(2)$ \\
\hline Bhadrakali & $28^{\circ} 12^{\prime} 53.4^{\prime \prime}$ & $84^{\circ} 00^{\prime} 27.5^{\prime \prime}$ & 882 & + & + & + & $1(2)$ & + & + & + & $1(2)$ \\
\hline Gumba & $28^{\circ} 13^{\prime} 20.8^{\prime \prime}$ & $83^{\circ} 59^{\prime} 37.9^{\prime \prime}$ & 866 & + & + & + & + & $1(2)$ & + & + & $1(2)$ \\
\hline Bagar & $28^{\circ} 14^{\prime} 37.5^{\prime \prime}$ & $33^{\circ} 56^{\prime} 10.1^{\prime \prime}$ & 919 & + & $1(0)$ & + & $1(2)$ & + & + & + & $2(2)$ \\
\hline Batulechaur & $28^{\circ} 15^{\prime} 11.2^{\prime \prime}$ & $83^{\circ} 59^{\prime} 7.5^{\prime \prime}$ & 943 & + & + & + & + & + & $1(2)$ & + & $1(2)$ \\
\hline Lamachaur & $28^{\circ} 26^{\prime} 13.1^{\prime \prime}$ & $83^{\circ} 97^{\prime} 21^{\prime \prime}$ & 945 & + & + & + & + & + & + & $1(0)$ & $1(0)$ \\
\hline Parsyang & $28^{\circ} 13^{\prime} 41.1^{\prime \prime}$ & $83^{\circ} 58^{\prime} 54.0^{\prime \prime}$ & 890 & $1(2)$ & $1(0)$ & + & $1(0)$ & + & + & + & $3(2)$ \\
\hline Airport & $28^{\circ} 12^{\prime} 04.9^{\prime \prime}$ & $83^{\circ} 58^{\prime} 48.1^{\prime \prime}$ & 822 & $1(2)$ & + & + & + & + & + & + & $1(2)$ \\
\hline Birauta & $28^{\circ} 10^{\prime} 45.9^{\prime \prime}$ & $83^{\circ} 58^{\prime} 52.8^{\prime \prime}$ & 765 & + & $1(3)$ & + & + & + & + & + & $1(3)$ \\
\hline Total & & & & $2(4)$ & $3(3)$ & $1(2)$ & $3(4)$ & $1(2)$ & $1(2)$ & $1(0)$ & $12(17)$ \\
\hline
\end{tabular}

+ tree occupied by the bird but no nest, number outside parenthesis indicates the number of the nest, number in parenthesis () indicates the number of chicks. 
Table 2. The coefficient of correlation of different variables of nesting trees.

\begin{tabular}{llllll}
\hline & $\mathrm{NN}$ & $\mathrm{NC}$ & $\mathrm{DBH}$ & $\mathrm{CC}$ & $\mathrm{TH}$ \\
\hline $\mathrm{NN}$ & & 1 & 1 & 1 & 1 \\
$\mathrm{NC}$ & 0 & & 0.16667 & 0.27778 & 0.16667 \\
$\mathrm{DBH}$ & 0 & -0.63901 & & 0.096798 & 0.33626 \\
$\mathrm{CC}$ & 0 & -0.45644 & 0.58333 & & 0.88009 \\
$\mathrm{TH}$ & 0 & 0.54772 & -0.36667 & 0.05 & \\
\hline
\end{tabular}

$(\mathrm{NN}=$ Number of nests, $\mathrm{NC}=$ Number of chicks, $\mathrm{DBH}=$ Diameter at Breast Height, $\mathrm{CC}=$ Canopy cover, $\mathrm{TH}=$ Tree Height).

\section{Discussion}

The present study revealed that Black kite is distributed throughout the valley and distribution is influenced by food availability and nesting site. Among nine sampling blocks, 'Batulechaur' was found the most suitable place for Black kite as the block had the highest number of birds. It might be due to the availability of food, water and roosting trees. Mukundan et al. (2014) reported that raptors were decreasing, due to serious aircraft strikes in India and aerodromes were considered as potential sites for the mass death of Black kites. But, we did not record the death of any Black kite due to airstrikes. We found the Black kites roosting on large and mature trees but the population has decreased in Pokhara valley. The present findings coincided with Sergio et al. (2003) who found a similar result that Black kites built a nest and roosted on more mature trees far from paths, villages and rugged steep microsites in Italian pre-Alps. Further, he reported the effects of climates on population variation. However, the effects of climates on the Black kite population was not carried out during the present study. FergusonLees and Christie (2001) reported that poisoned carcass and water pollution seems to main causes of the decline in the population of the Black kite in Europe and parts of Asia. Such conditions were not found in the present study.

\section{Breeding success}

The breeding success of Black kite was found $47.22 \%$ in Pokhara valley. A similar result was found by Vinuela and Sunyer (1992) in the study of 182 nest sites of the Black kite in two areas of south and central Spain. They found that orientations toward the east were preferred. The data suggest that rainfall and prevailing winds were the main factors conditioning nest orientation. Sergio and Boto (1999) found the low success were unclear, but may have been related to low food availability or water pollution and consequent pesticide contamination in Italy. They found the mean clutch size was 2.29 eggs $(n=42)$ in Italy which was quite higher than our findings we have recorded an average clutch size of 1.88. Sergio et al. (2003) found that tree-nests were located in the most mature tree in the stand. Human disturbance limited foraging and breeding performance. Kumar et al. (2014) believed that the density of Black kites in Delhi, India, may represent the highest concentration of a raptor recorded in the world and has not declined since the 1960s.

The population of Black kites was found comparatively high during the pre-breeding season compared to the post-breeding season in Pokhara valley. Altogether 12 nests were recorded on seven different tree species. Of which, eight nests were active, having eggs and chicks. Mortality was nil, it might be due to the availability of sufficient food.

\section{Threats}

Previous data on the population status of Black kites were not available. Based on the present census, it was found that the population of the kite was comparatively less as compared to two decades ago. The number of Black kites found gradually declined mainly due to anthropogenic activities like felling down nesting trees especially Fragrant Bay (Machilus odoratissima) to construct their houses and to clear the site for road construction. For the conservation of Black kites from the study area, awareness programmes should be launched among local farmers. The importance of nesting trees, impacts of poisoned carcasses, effects of excessive use of chemical fertilizers, pesticides on raptors should be emphasized. 


\section{Acknowledgements}

We would like to express our sincere gratefulness to Prof. Dr. Damodar Thapa Chhetry, Head, Department of Zoology, Post Graduate Campus for moral support and encouragement. We are sincerely grateful to $\mathrm{Mr}$. Jay Narayan Shrestha, Assistant Campus Chief, Post Graduate Campus, Biratnagar for his valuable suggestions. We are grateful to Dr. Bharat Raj Subba, Associate Professor for his inspiration and valuable comments. We acknowledge Prof. Dr. Chandra Bahadur Thapa, Ex-Campus Chief, Prithivi Narayan Campus, Pokhara for his continuous guidance, support and inspiration.

\section{References}

Ali, S., Ripley, S. D. and Dick, J. H. 1995. A pictorial guide to the Birds of the Indian Subcontinent. Oxford University Press. $274 \mathrm{p}$.

Arlott, N. 2015. Collins field guide Birds of India, Pakistan, Nepal, Bhutan, Bangladesh and Sri Lanka (eBook edit). William Collins, An imprints of Harper Collins Publishers, London Bridge Street. 400p.

BCN 2016. Annual report on urban bird monitoring program in Kathmandu valley, Nepal. www.birdlifenepal.org

Climate Data 2021. Climate Pokhara Nepal. Climate Data.Org. https://en.climatedata.org/asia/nepal/western-developmentregion/pokhara-613/

Ferguson-Lees, J. and Christie, D. A. 2001. Raptors of the world. Christopher Helm Publishers, Ltd, 36 Soho Square, London. 993p.

Ghimire, P., Pandey, N., Belbase, B., Ghimire, R., Khanal, C., Bist, B. S. and Bhusal, K. P. 2020. If you go, I'll stay: nest use interaction between Asian Woollyneck Ciconia episcopus and Black kite Milvus migrans in Nepal. BirdingASIA, 33(9): 103-105.

Grewal, B., Harvey, B. and Pfister, O. 2002. A photographic guide to the birds of India and the Indian subcontinent including Pakistan, Nepal, Bhuan, Bangladesh, Sri Lanka and Maldives. Periplus Editions (HK) Ltd. 1853p.

Grimmett, R., Inskipp, C. and Inskipp, T. 2014. Helm Field Guide Birds of the Indian Subcontinent. Christopher Helm, an imprint of Bloomsbury Publishing PPlc, 50 Bedford Square, London. 556p.

Heneberg, P., Dolinay, M., Matušík, H., Pfeiffer, T., Nachtigall, W., Bizos, Šimčíková D. and Literák, I. 2016. Conservation of the red kite Milvus milvus (Aves: Accipitriformes) is not affected by the establishment of a broad hybrid zone with the black kite Milvus migrans migrans in Central Europe. PloS one, 11(7), e0159202.

Inskipp, C. and Inskipp, T. 1985. Guide to the Birds of Nepal. Christopher Helm (Publishers) Ltd. 420p.

Inskipp, C., Phuyal, S., Bhatta, T. R., Khatiwada, M., Inskipp, T., Gurung, S., Singh, P. B., Murray, L., Poudyal, L. and Amin, R. 2016. The status of Nepal's birds: the national red list series. In Zoological Society of London (Vol. 1).

Juhant, M. A. and Bildstein, K. L. 2017. Raptor migration across and around the Himalayas. Bird Migration Across the Himalayas: Wetland Functioning amidst Mountains and Glaciers, April, 98-116. https://doi.org/10.1017/9781316335420.00 9

Kharel, M. 2018. General survey on the avifaunal composition of Betana wetland, Morang, Province number 1, Eastern Nepal. Bibechana, 16: 154-164. https://doi.org/10.3126/bibechana.v16i0.21 570

Kumar, N., Mohan, D., Jhala, Y. V, Qureshi, Q. and Sergio, F. 2014. Density, laying date, breeding success and diet of Black kites Milvus migrans govinda in the city of Delhi (India). Bird Study 61(1): 1-8. https://doi.org/10.1080/00063657.2013.876 972

Literák, I., Horal, D., Alivizatos, H. and Matušík, H. 2017. Common wintering of Black kites (Milvus migrans migrans) in Greece, and new data on their wintering elsewhere in Europe. Slovak Raptor Journal, 11(1): 91102. https://doi.org/10.1515/srj-2017-0001

Llorente-Llurba, E. 2019. Diet composition and breeding success of the Black-winged kite on the Lleida plains in relation to population size. Ardeola, 66(1): 33-50. https://doi.org/10.13157/arla.66.1.2019.ra3

Mazumdar, S., Ghose, D. and Saha, G. K. 2017a. Communal roosting behaviour of the Black kite (Milvus migrans govinda) in an urban metropolis. Journal of Ethology, 35(3): 
Khand, Adhikaree, Kharel and Gautam / Our Nature | December 2021 | 19 (1): 46-53

269-277. https://doi.org/10.1007/s10164017-0516-x

Mazumdar, S., Ghose, D. and Saha G. K. 2017b. Nests of Black kite (Milvus migrans govinda) in urban landscape of Kolkata, India. Proceedings of the Zoological Society, 70(2): 201-205. https://doi.org/10.1007/s12595-015-0163-6

Metropolitan, P. 2021. Pokhara mertopolitancity profile. In Pokhara Mertopolitancity. Pokhara Mertopolitancity. www.pokharamun.gov.np

Mukundan, S., Arunaksharan, N. and Jose, B. 2014. A Preliminary study on the ecology and biology of Black kites ( Milvus migrans ) in Kozhikode City, Kerala. September. 273-275.

Panuccio, M., Agostini, N., Mellone, U. and Bogliani, G. 2014. Circannual variation in movement patterns of the Black kite (Milvus migrans migrans): a review. Ethology Ecology \and Evolution, 26(1): 118.

https://doi.org/10.1080/03949370.2013.812 147

Richrds, A. 1998. Birds of Prey: Hunters of the Sky. Courage Books Publications. 144p.

Sergio, F. and Boto, A. 1999. Nest dispersion, diet, and breeding success of Black kites (Milvus migrans) in the Italian pre-Alps. Journal of Raptor Research, 33(3): 207217.

Sergio, F., Pedrini, P. and Marchesi, L. 2003. Adaptive selection of foraging and nesting habitat by Black kites (Milvus migrans) and its implications for conservation: A multiscale approach. Biological Conservation, 112(3): 351-362. https://doi.org/10.1016/S00063207(02)00332-4

Sharma, S. K. and Soni, K. C. 2017. Feeding behaviour of Indian Black kite (Milvus migrans) inhabiting the arid zone of Rajasthan. International Journal of Zoology Studies, 2(5): 58-61.

Sharma, S. and Soni, K. C. 2018. Seasonal variation in the population of Black kite (Milvus migrans), inhabiting the Arid Zone of Rajasthan. Journal of Advances in Biology, 9(4): 154-161. https://doi.org/10.24297/jab.v9i4.6364

Vinuela, J. and Sunyer, C. 1992. Nest orientation and hatching success of Black kites Milvus migrans in Spain. Ibis, 134(4): 340-345. https://doi.org/10.1111/j.1474919X.1992.tb08013.x 